\title{
The Analysis on Emissions Impact Factors of Generator Set Based on SPSS Software
}

\author{
Mengqi Liu
}

\begin{abstract}
During the National Twelfth Five-Year Plan period, the government has carried on the strict control of emissions of sulfur dioxide and nitrogen oxides, and made the standards of the amount of energy saving and emission reduction for the whole society. As great emitter, electric power industry is facing from the dual pressure of the targets and the power supply shortage. Therefore, how to realize power supply optimization under the environmental protection index will be an important direction of the electric power industry development in the future. In this paper, a single generator is regard as the research object. By using SPSS statistical tools and the analysis methods of Spearman and Chi square, the relevance among coal consumption rate, power generation, integrated plant electricity rate of the unit's electricity, delivery, $\mathrm{SO}_{2}$ emissions and $\mathrm{NO}_{\mathrm{x}}$ emissions is verified in the research. The research conclusion can provide basis and feasible research direction for the further study that how to achieve maximum capacity under environmental protection index constraints in electric power industry.
\end{abstract}

Index Terms-Energy conservation and emission reduction, power industry, influence factor, SPSS, correlation analysis.

\section{INTRODUCTION}

During the National Twelfth Five-Year Plan period, the Chinese government put forward the strategic decision of total emission reduction of essential pollutants.

As binding forces, sulfur dioxide and nitrogen oxides make environmental protection be put forefront. Local governments have to regard the environmental protection as an important consideration while developing the economy. Emission reduction of main pollutants becomes the key of environmental protection

As one of two kinds of control target of emission reduction, the emissions of $\mathrm{SO}_{2}$ in China reach the peak in 2006 and decline year by year after that as well as the nitrogen oxide emissions are decreasing year by year. [1] However, the power industry is still a huge emitter to contribute to the environmental pollution.

On a global scale, power production accounted for $32 \%$ of total fossil fuel use, taking up $41 \%$ of $\mathrm{CO}_{2}$ emissions related to the energy. [1]

According to the IEA data, if the global fossil fuel power generation could be able to achieve the best efficiency (according to the technical feasibility estimate), there will be 716 million 989 million tce energy saved per year $(501 \sim$ 692 mtoe) and reduce 1.8 billion -2.5 billion tons of $\mathrm{CO}_{2}$. The

Manuscript received February 15, 2014; revised June 20, 2014.

Liu Mengqi is with the North China Electric Power University, P.R China (e-mail: 449032128@qq.com). "largest coal" is fired power. Generation potential (saving 512 million $\sim 716$ million tce energy, 1.4 billion $\sim 2$ billion tons of $\mathrm{CO}_{2}$ ). In our country, the electric power industry is the basic industry and the main energy industry of national economy, and it is also one of the major energy resource consumption and pollutant emissions industry as well.

According to the date of <China's environment statistical yearbook 2010>, coal consumption of power department in 2009 accounted for more than half of the total coal consumption of industrial sectors, and its sulfur dioxide emissions accounted for $55 \%$ of the national emissions. [2]

In the late $1970 \mathrm{~s}$, the industrialized countries actively explored methods to control $\mathrm{SO}_{2}$ emissions, willing to reduce the harm of acid rain.

The major acid rain areas of the world took effective measures to control sulfur dioxide emissions.

The major factors affecting the power production $\mathrm{SO}_{2}$ emissions are generating unit, the form of parameters, and the age of the unit, etc. Only a correct understanding of the influence factors of $\mathrm{SO}_{2}$ emission in electric power industry and comprehensive evaluation of various power plants for $\mathrm{SO}_{2}$ emissions can refine the total emissions targets and reasonable allocation. [3] On the premise of guarantee, the economic development and effective realization of $\mathrm{SO}_{2}$ emission will reduce for long.

\section{OVERSEAS AND DOMESTIC RESEARCH STATUS}

\section{A. Research Status of $\mathrm{SO}_{2}$ and $\mathrm{NO}_{X}$ Emissions Control for Electric Power Production}

\section{1) The basic concept of total amount control}

Total amount control is short for pollutant total amount control. [4] According to the regional environmental targets (environmental quality target or targets), calculating the environment in advance is the most important goal under limit of the pollutant emissions. And through the optimization calculation, it will allow the emissions of pollutants indicators assigned to each pollution source, and the distribution of the emission index should be according to the different geographical position of various pollutants in technology level and economic bear ability.

Total amount control should include three aspects of content, one is that the total emission of pollutants, the second is the discharge of pollutants, three is the time of discharge of pollutants. Therefore, the total amount control is refers to the control units within a certain time area pollutant (determined by the laws and regulations need to control the pollutants) emissions means of environmental management. 


\section{2) Total amount control status at home and abroad}

Plan CCT (Clean Coal Technology) of USA was put forward by the U.S. department of energy (DOE) in 1986. It started in 1985 from the research of how to solve the problem of acid rain transit in America and Canada. Therefore, at the beginning, the plan just work for acid problem, after that, it expand target for the development of the next generation of super clean and efficient coal-fired power plants.

CCT plan seeks to build a large numbered, advanced, efficient and environmental technology market of coal utilization energy. The technology which will be commercialized, reflect the strategic position of coal in the American economy. At present, more than $50 \%$ of electricity is produced by coal-fired power stations, and power-short areas are not only limited to California in the United States.

In China, the plan of total main pollutant control is approved by the state council. As a national control plan indicators, it works among the provinces, autonomous regions, and municipalities directly under the central government [5].

In the plan, the pollution gross cardinal number is result from the statistical data of environment and pollution coefficient, being a kind of national macro control targets.

Provinces, autonomous regions, and municipalities determine the pollutant total amount allocation weights or influence coefficient on the basis of total emission amount control target required by the state, then decompose the total amount control into different areas under administration as control index [6].

Current method for total amount control has pointed out the direction to realize $\mathrm{SO}_{2}$ emissions control, but in the specific process of indicators (especially provinces and cities designated quota) there are no unified scientific allocation methods.

As for power industry which is dominant in the $\mathrm{SO}_{2}$ emission, the problem is mainly due to the lack of an understanding of the $\mathrm{SO}_{2}$ emission factors and calculation, making the distribution gaps between the plans and the actual often.

\section{B. Research Status of $\mathrm{SO}_{2}$ and $\mathrm{NO}_{X}$ Emission Factors of Electric Power Production}

Nowadays there is lack of studies for $\mathrm{SO}_{2}$ emission factors in electric power production around the world. Most studies are limited to the list but did not calculate it with the relevance of the $\mathrm{SO}_{2}$ and $\mathrm{NO}_{\mathrm{X}}$ emissions.

Some studies of $\mathrm{SO}_{2}$ emissions in electric power industry are not explicitly scientific research to find out the influence factors on the relationship between the emission and the specific emission factor.

\section{The Main Content in This Study Paper}

This article is to deeply analyze and prove the influence factors of $\mathrm{SO}_{2}$ and $\mathrm{NO}_{\mathrm{X}}$ emissions by the correlation identification method under the premise of the targeted emission total control.

In generating set, using Spearman and Chi square analysis method in SPSS statistical software to analyze the correlation of the factors and pollution emissions, and provide reference and basis for studying the largest electricity under the restriction of the environmental protection index.

\section{STUDY DESIGN}

\section{A. Study Model and Related Concepts}

The independent variables of this study are the main characteristics of the generator set, and the dependent variables are $\mathrm{SO}_{2}$ and $\mathrm{NO}_{\mathrm{X}}$ emission factor. The analysis model is built based on the variables above.

Select of coal consumption rate, power generation, integrated plant electricity rate, delivery to measure the independent variable and do the data analysis based on the actual investigation data structure and corresponding econometric model. According to the empirical results we could find the relationship between the generator characteristic factors and the pollutant emissions.

The original data of the present study was 35 coal-fired power unit information from 13 coal-fired power plant in Shanghai

The Correlation Coefficient numerical size according to the correlation of absolute value of size; the null hypothesis between the variables is there is no relation between the two in the case of uncertainty relation of plus or minus.

Choose 2 tails test (Sig. (2 - tailed)) and plus or minus symbol signify the positive correlation and the negative correlation; Significant judgment is according to the requirements of statistical standards. If its value is lower than 0.05 , means significant strongly. [7]

What extent can we trust the relationship that we get, that is, the relationship between the degree of confidence (1 significant) $\%$.

\section{B. Analytical Method}

As for the analysis method, the paper use descriptive analysis, correlation analysis and other statistical analysis method to describe intuitive correlation between pollutants discharge and the electric power industry.

\section{CORRELATION ANALYSIS}

First of all, 35 typical samples were selected to study, then by the method of using independent sample T-test to verify the effectiveness of the selected seven variables with identification degree and significant difference (see Table I).

Seven variables in the Levene test in coal consumption rate and integrated plant electricity rate value was not significant (sig value is greater than 0.05 ), the remaining five variables $\mathrm{F}$ value are significant, and all the seven variables corresponding $\mathrm{t}$ value was significantly (sig value is less than 0.05. So we can determine the seven variables have distinctiveness and significant difference, as the research object.

\section{A. Coal Consumption Rate and Pollutant Emissions}

In the study of factor of coal consumption rate and $\mathrm{SO}_{2}$ and $\mathrm{NO}_{\mathrm{X}}$ emission, the unit coal consumption rate and the NOX emission factor positively correlated on the confidence level of $99.6 \%$, and the correlation coefficient is $56.9 \%$, showing that the positive correlation of coal consumption rate of the unit and $\mathrm{NO}_{\mathrm{X}}$ emissions present have high confidence. In the process of control nitrogen oxide emissions, coal consumption of unit should be highly considered. 
TABLE I: INDEPENDENT SAMPLE TEST

\begin{tabular}{|c|c|c|c|c|c|c|c|c|c|c|}
\hline & & \multicolumn{2}{|c|}{$\begin{array}{l}\text { Levene test } \mathrm{o} \\
\text { variance equations }\end{array}$} & \multicolumn{7}{|c|}{ The mean equation of $t$ test } \\
\hline & & & & & & & & & $\begin{array}{l}\text { The diffe } \\
95 \% \\
\text { interval }\end{array}$ & $\begin{array}{l}\text { ce of the } \\
\text { onfidence }\end{array}$ \\
\hline & & $\mathrm{F}$ & Sig. & $\mathrm{T}$ & Df & $\begin{array}{l}\text { Sig.(do } \\
\text { uble) }\end{array}$ & $\begin{array}{l}\text { The mean } \\
\text { difference }\end{array}$ & $\begin{array}{l}\text { Standard error } \\
\text { values }\end{array}$ & $\begin{array}{l}\text { lower } \\
\text { limit }\end{array}$ & $\begin{array}{l}\text { upper } \\
\text { limit }\end{array}$ \\
\hline \multirow{2}{*}{$\begin{array}{l}\text { coa } \\
\text { consump } \\
\text { tion rate }\end{array}$} & $\begin{array}{l}\text { Equal Variances } \\
\text { Assumed }\end{array}$ & .001 & .978 & -3.894 & 33 & .000 & -0.03 & 0.01 & -0.04 & -0.01 \\
\hline & $\begin{array}{l}\text { Equal Variances } \\
\text { Not Assumed }\end{array}$ & & & -4.435 & 32.998 & .000 & -0.03 & 0.01 & -0.04 & -0.02 \\
\hline \multirow{2}{*}{$\begin{array}{l}\text { generati } \\
\text { ng } \\
\text { capacity }\end{array}$} & $\begin{array}{l}\text { Equal Variances } \\
\text { Assumed }\end{array}$ & 26.819 & .000 & 9.085 & 33 & .000 & 32.25 & 3.55 & 25.03 & 39.48 \\
\hline & $\begin{array}{l}\text { Equal Variances } \\
\text { Not Assumed }\end{array}$ & & & 7.695 & 15.408 & .000 & 32.25 & 4.19 & 23.34 & 41.17 \\
\hline \multirow{2}{*}{$\begin{array}{l}\text { Integrate } \\
\text { d plant } \\
\text { electricit } \\
\text { y rate }\end{array}$} & $\begin{array}{l}\text { Equal Variances } \\
\text { Assumed }\end{array}$ & 3.262 & .080 & -2.721 & 33 & .010 & -2.81 & 1.03 & -4.91 & -0.71 \\
\hline & $\begin{array}{l}\text { Equal Variances } \\
\text { Not Assumed }\end{array}$ & & & -3.523 & 22.419 & .002 & -2.81 & 0.80 & -4.46 & -1.16 \\
\hline \multirow[t]{2}{*}{ Delivery } & $\begin{array}{l}\text { Equal Variances } \\
\text { Assumed }\end{array}$ & 27.626 & .000 & 9.129 & 33 & .000 & 3107260.13 & 340373.04 & $\begin{array}{l}2414765 . \\
97\end{array}$ & $\begin{array}{l}379975 \\
4.30\end{array}$ \\
\hline & $\begin{array}{l}\text { Equal Variances } \\
\text { Not Assumed }\end{array}$ & & & 7.720 & 15.343 & .000 & 3107260.13 & 402520.42 & $\begin{array}{l}2250976 . \\
02\end{array}$ & $\begin{array}{l}396354 \\
4.24\end{array}$ \\
\hline \multirow{2}{*}{$\begin{array}{l}\mathrm{SO}_{2} \\
\text { emission } \\
\text { factor }\end{array}$} & $\begin{array}{l}\text { Equal Variances } \\
\text { Assumed }\end{array}$ & 7.939 & .008 & -1.616 & 33 & .116 & 0.00 & 0.00 & 0.00 & 0.00 \\
\hline & $\begin{array}{l}\text { Equal Variances } \\
\text { Not Assumed }\end{array}$ & & & -2.106 & 21.497 & .047 & 0.00 & 0.00 & 0.00 & 0.00 \\
\hline \multirow{2}{*}{$\begin{array}{l}\mathrm{NO}_{\mathrm{X}} \\
\text { emission } \\
\text { factor }\end{array}$} & $\begin{array}{l}\text { Equal Variances } \\
\text { Assumed }\end{array}$ & 15.199 & .000 & -1.930 & 33 & .062 & -0.01 & 0.00 & -0.01 & 0.00 \\
\hline & $\begin{array}{l}\text { Equal Variances } \\
\text { Not Assumed }\end{array}$ & & & -2.520 & 21.265 & .020 & -0.01 & 0.00 & -0.01 & 0.00 \\
\hline \multirow{2}{*}{$\begin{array}{l}\text { Compre } \\
\text { hensive } \\
\text { emission } \\
\text { factors }\end{array}$} & $\begin{array}{l}\text { Equal Variances } \\
\text { Assumed }\end{array}$ & 27.021 & .000 & -2.259 & 33 & .031 & 0.00 & 0.00 & -0.01 & 0.00 \\
\hline & $\begin{array}{l}\text { Equal Variances } \\
\text { Not Assumed }\end{array}$ & & & -2.949 & 21.356 & .008 & 0.00 & 0.00 & 0.00 & 0.00 \\
\hline
\end{tabular}

TABLE II: THE CORRELATION COEFFICIENT OF COAL CONSUMPTION RATE

\begin{tabular}{|c|c|c|c|c|c|}
\hline & & & $\begin{array}{l}\text { coa } \\
\text { consump- } \\
\text { tion rate }\end{array}$ & $\begin{array}{l}\mathrm{SO}_{2} \\
\text { emission } \\
\text { factor }\end{array}$ & $\begin{array}{l}\mathrm{NO}_{X} \\
\text { emission } \\
\text { factor }\end{array}$ \\
\hline \multirow{9}{*}{$\begin{array}{l}\text { Sp } \\
\text { ear } \\
-\mathrm{m} \\
\text { an' } \\
\text { s } \\
\text { rho }\end{array}$} & \multirow{3}{*}{$\begin{array}{l}\text { coal } \\
\text { consumpt } \\
\text { ion rate }\end{array}$} & correlation coefficient & 1.000 & $.474 * *$ & $.569 * *$ \\
\hline & & Sig. (double) & . & .006 & .004 \\
\hline & & $\mathrm{N}$ & 35 & 35 & 35 \\
\hline & \multirow{3}{*}{$\begin{array}{l}\mathrm{SO}_{2} \\
\text { emission } \\
\text { factor }\end{array}$} & correlation coefficient & $.474 * *$ & 1.000 & .046 \\
\hline & & Sig. (double) & .006 & . & .832 \\
\hline & & $\mathrm{N}$ & 35 & 35 & 35 \\
\hline & \multirow{3}{*}{$\begin{array}{l}\mathrm{NO}_{\mathrm{X}} \\
\text { emission } \\
\text { factor }\end{array}$} & correlation coefficient & $.569 * *$ & .046 & 1.000 \\
\hline & & Sig. (double) & .004 & .832 & . \\
\hline & & $\mathrm{N}$ & 35 & 35 & 35 \\
\hline
\end{tabular}

**. When confidence (double) measurement is 0.01 , the correlation is significant

While coal consumption rate and $\mathrm{SO}_{2}$ emission factor presents the confidence level of $99.4 \%$. The result shows the significantly higher but the correlation is only $47.4 \%$ positive correlation, which is means that correlation is not high enough to explain the relationship between (see Table II).

\section{B. Power Generation and Pollutant Emissions}

In the correlation of power generation and emission factor inspection, we found that the correlation output the $\mathrm{NO}_{\mathrm{X}}$ emission is more closely related to the characteristics, in $100 \%$ of the negative correlation degree. Correlation coefficients up to $75.5 \%$ (see Table III).

That is to say, the unit installed capacity of $\mathrm{NO}_{\mathrm{X}}$ emission factor is smaller and the discharge of pollutants per unit of electricity generated is less. The test provides strong theoretical support for the country shutting down small thermal power plants and also provides a feasible direction for the next step of reduction. Data shows that the confidence degree of power and the correlation coefficient of $\mathrm{SO}_{2}$ is higher, significant at $99 \%$. While the correlation coefficient is only $42.9 \%$, it can be seen that the $\mathrm{SO}_{2}$ emissions and electricity have not very obviously negative correlation relationship.

TABLE III: THE CORRELATION COEFFICIENT OF GENERATING CAPACITY

\begin{tabular}{|c|c|c|c|c|c|}
\hline & & & $\begin{array}{l}\text { generating } \\
\text { capacity }\end{array}$ & $\begin{array}{l}\mathrm{SO}_{2} \\
\text { emission } \\
\text { factor }\end{array}$ & $\begin{array}{l}\mathrm{NO}_{X} \\
\text { emission } \\
\text { factor }\end{array}$ \\
\hline \multirow{9}{*}{$\begin{array}{l}\text { Spear } \\
\text {-man' } \\
\text { s rho }\end{array}$} & \multirow{3}{*}{$\begin{array}{l}\text { generating } \\
\text { capacity }\end{array}$} & $\begin{array}{l}\text { correlation } \\
\text { coefficient }\end{array}$ & 1.000 & $-.429 *$ & $-.755^{* *}$ \\
\hline & & Sig. (double) & . & .010 & .000 \\
\hline & & $\mathrm{N}$ & 35 & 35 & 35 \\
\hline & \multirow{3}{*}{$\begin{array}{l}\mathrm{SO}_{2} \\
\text { emission } \\
\text { factor }\end{array}$} & $\begin{array}{l}\text { correlation } \\
\text { coefficient }\end{array}$ & $-.429 *$ & 1.000 & $.541 * *$ \\
\hline & & Sig. (double) & .010 & . & .001 \\
\hline & & $\mathrm{N}$ & 35 & 35 & 35 \\
\hline & \multirow{3}{*}{$\begin{array}{l}\mathrm{NO}_{\mathrm{X}} \\
\text { emission } \\
\text { factor }\end{array}$} & $\begin{array}{l}\text { correlation } \\
\text { coefficient }\end{array}$ & $-.755^{* *}$ & $.541 * *$ & 1.000 \\
\hline & & Sig. (double) & .000 & .001 & . \\
\hline & & $\mathrm{N}$ & 35 & 35 & 35 \\
\hline
\end{tabular}

*. When confidence (double) measurement is 0.05 , the correlation is significant

**. When confidence (double) measurement is 0.01 , the correlation is significant

\section{Integrated Plant Electricity Rate and Pollutant}

Emissions

In the study of integrated plant electricity rate and pollutants in the inspection we found that integrated plant 
electricity rate and NOX emission factor has obvious negative correlation. The correlation coefficient is $49.7 \%$, and the number of the $\mathrm{NO}_{\mathrm{X}}$ emission factor variance have a big part in related to integrated plant electricity rate. However, the correlation between $\mathrm{SO}_{2}$ and emissions is not very significant, but it is still stable within the $0.05,0.12$, and a low correlation coefficient is $16.6 \%$ (see Table IV) we can think integrated plant electricity rate has correlation with chlorine dioxide emissions, but the correlation is weak.

TABLE IV: THE CORRELATION COEFFICIENT OF INTEGRATED PLANT ELECTRICITY

\begin{tabular}{|c|c|c|c|c|c|}
\hline \multirow{10}{*}{$\begin{array}{l}\text { Spear- } \\
\text { man's } \\
\text { rho }\end{array}$} & & & $\begin{array}{l}\text { Integrated } \\
\text { plant } \\
\text { electricity }\end{array}$ & $\begin{array}{l}\mathrm{SO}_{2} \\
\text { emission } \\
\text { factor }\end{array}$ & $\begin{array}{l}\mathrm{NO}_{X} \\
\text { emission } \\
\text { factor }\end{array}$ \\
\hline & \multirow{3}{*}{$\begin{array}{l}\text { Integrated } \\
\text { plant } \\
\text { electricity }\end{array}$} & $\begin{array}{l}\text { correlation } \\
\text { coefficient }\end{array}$ & 1.000 & -.166 & $-.497^{* *}$ \\
\hline & & Sig. (double) & . & .012 & .002 \\
\hline & & $\mathrm{N}$ & 35 & 35 & 35 \\
\hline & \multirow{3}{*}{$\begin{array}{l}\mathrm{SO}_{2} \\
\text { emission } \\
\text { factor }\end{array}$} & $\begin{array}{l}\text { correlation } \\
\text { coefficient }\end{array}$ & -.166 & 1.000 & $.541^{* *}$ \\
\hline & & Sig. (double) & .012 & . & .001 \\
\hline & & $\mathrm{N}$ & 35 & 35 & 35 \\
\hline & \multirow{3}{*}{$\begin{array}{l}\mathrm{NO}_{\mathrm{X}} \\
\text { emission } \\
\text { factor }\end{array}$} & $\begin{array}{l}\text { correlation } \\
\text { coefficient }\end{array}$ & $-.497^{* *}$ & $.541^{\text {*** }}$ & 1.000 \\
\hline & & Sig. (double) & .002 & .001 & . \\
\hline & & $\mathrm{N}$ & 35 & 35 & 35 \\
\hline
\end{tabular}

TABLE V: THE CORRELATION COEFFICIENT OF DELIVERY

\begin{tabular}{|c|c|c|c|c|c|}
\hline & & & Delivery & $\begin{array}{l}\mathrm{SO}_{2} \\
\text { emission } \\
\text { factor }\end{array}$ & $\begin{array}{l}\mathrm{NO}_{\mathrm{X}} \\
\text { emission } \\
\text { factor }\end{array}$ \\
\hline \multirow{9}{*}{$\begin{array}{l}\text { Spear- } \\
\text { man's } \\
\text { rho }\end{array}$} & \multirow{3}{*}{ Delivery } & $\begin{array}{l}\text { correlation } \\
\text { coefficient }\end{array}$ & 1.000 & $-.430^{*}$ & $-.755^{* *}$ \\
\hline & & Sig. (double) & . & .010 & .000 \\
\hline & & $\mathrm{N}$ & 35 & 35 & 35 \\
\hline & \multirow{3}{*}{$\begin{array}{l}\mathrm{SO}_{2} \\
\text { emission } \\
\text { factor }\end{array}$} & $\begin{array}{l}\text { correlation } \\
\text { coefficient }\end{array}$ & $-.430^{*}$ & 1.000 & $.541^{* * *}$ \\
\hline & & Sig. (double) & .010 & . & .001 \\
\hline & & $\mathrm{N}$ & 35 & 35 & 35 \\
\hline & \multirow{3}{*}{$\begin{array}{l}\mathrm{NO}_{\mathrm{X}} \\
\text { emission } \\
\text { factor }\end{array}$} & $\begin{array}{l}\text { correlation } \\
\text { coefficient }\end{array}$ & $-.755^{* *}$ & $.541^{* *}$ & 1.000 \\
\hline & & Sig. (double) & .000 & .001 & . \\
\hline & & $\mathrm{N}$ & 35 & 35 & 35 \\
\hline
\end{tabular}

*. When confidence (double) measurement is 0.05 , the correlation is significant $* *$. When confidence (double) measurement is 0.01 , the correlation is significant

\section{Delivery and Pollutant Emissions}

The result of delivery study is close to capacity, showing a high credibility of negative relationship with $\mathrm{NO}_{\mathrm{X}}$ and $\mathrm{SO}_{2}$ emission factors. Confidence of $\mathrm{SO}_{2}$ emission factor is lower than $\mathrm{NO}_{\mathrm{X}}$ (see Table V). But due to the large amount of data, the data has strong toughness, so we can think that there is a strong correlation between the two.

\section{CONCLUSION AND SUGgestions}

A. $\mathrm{NO}_{\mathrm{X}}$ and $\mathrm{SO}_{2}$ shows the opposite correlation under the influence of such aspects of factors like integrated plant electricity rate, so the emission reduction measures should be highly consider the difference between research, according to the actual situation around the implementation of a bias measures to reduce pollutants discharge.

B. $\mathrm{SO}_{2}$ emissions has set up a file that generating has mainly realized a complete coverage of desulfurizer in the national 11th five-year plan, and the $\mathrm{NO}_{\mathrm{X}}$ emission is a new request in national 12th five-year plan. By 2012, few power generatings have installed out-of-stock device. $\mathrm{NO}_{\mathrm{X}}$ emissions reduction shall, first of all, starting from a complete coverage of out of stock, and this measure will significantly reduce $\mathrm{NO}_{\mathrm{X}}$ discharge pressure.

\section{REFERENCES}

[1] P. Li and X. Wang, "Countermeasures for comprehensive management and control of pollutants in the city of our country," Environment and Sustainable Development, vol. 5, pp. 8-14, 2011.

[2] China Environment Yearbook, Beijing: China environment yearbook club, 2011 2010.

[3] R. Fu, "Technical and economic analysis of air pollutant emission standards of fossil-fuel power plant," Technical and Economic, vol. 23, no. 12, pp. 56-65, 2011.

[4] The National Energy Administration. (2012). Energy saving key technology development present situation of the electric power industry in our country. [Online]. Available:
[ http://www.nea.gov.cn/2012-01/12/c_131355690_2.htm.

[5] Z. P. Chen, "Comparing new edition standard for fossil-fuel power plant with the old one," North China Electric Power, vol. 12, pp. 53-55, 2012.

[6] Y. M. Xie, "Sulfur dioxide emissions from coal-fired power plants to control analysis in our country," Jilin University, China, pp. 17-23, 2002.

[7] X. H. Zheng, Economic Development and Village Democracy Chinese Experience in the Interpretation, Shanghai: Shanghai Jiao Tong University, 2012.

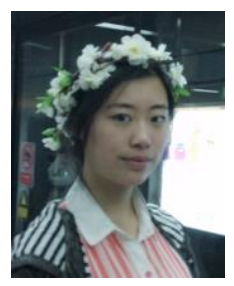

Mengqi Liu was born in Qingdao city of China, on September 8, 1992. She is now studying at the North China Electric Power University in Beijing. Her research is mainly on technological economics and human resource management.

She serves as the president of the website committee in university and an assistant of School Party Committee Organization Department. Meanwhile, she is also a research assistant who helps the teachers to do scientific research project. She has authored "Analysis about method factors of customer electrical payment based on the new model of marketing organization," in Economic Life Digest, 2013. 